\title{
SYLVIA IN SUFFOLK
}

Ronald Blythe

Sylvia was brought to my little farmhouse at Debach, Suffolk on Saturday 11th November 1967 by Michael Howard. Michael was the son of Wren Howard, the co-founder of Jonathan Cape the publisher. Michael and his wife Pat had recently come to live in Finborough a few miles south and had been introduced to me by Tony Godwin the brilliantly wayward genius of Viking-Penguin. Tony had asked me to write about rural change and when Sylvia arrived I was in the middle of Akenfield. I cannot recall saying much about it. On the whole writers tend to hold back from describing work in progress to another writer. In any case, I was overcome by having Sylvia Townsend Warner by my fireside. It was a grim half-lit autumn day, I remember, and just before she arrived the winter logs I had ordered had been unceremoniously tipped in the drive by John with, 'I got you hulva (holly) wood. Mind the sparks'. It was blazing dangerously when Sylvia arrived and it enchanted her. She mentioned it in her thankyou letter. Also the cake I had made for her. She was in her early seventies, sharp-jawed, lively eyes behind glinting glasses, and with a commanding voice. I saw her as one of those people who appreciated comfort because they had never been able to create much comfort in their lives. So she was openly appreciative with the hot old room and the spread tea.

I was to return with them to Finborough to dinner in Michael's grand car but what to do between the late afternoon and the early evening? Debach was in reach of a single 'sight' and this was the grave of the poet Edward FitzGerald at neighbouring Boulge. Would they like to visit it? 'The translator of The Rubaiyat of Omar Khayyam?' Sylvia was out 
of her armchair in a minute. And so we drove the couple of miles through the darkening lanes to the small church halfvisible through the tall trees where, below a rose brought from Omar's tomb at Naishipur, lay the tilting stone of Edward FitzGerald, the Suffolk-Irish writer and the friend of Tennyson and Carlyle. He was an odd person who put the blame on God, so his tomb is inscribed, 'It is He that hath made us, and not we ourselves'. Sylvia was delighted. When we went to look at the church a young airman from the U.S.A. base at Bentwaters, a baby in his arms, was feeling for the switch. 'Where is the light?' 'There is no light', said Sylvia surprisingly.

So that is how we met. At Finborough the conversation was mostly about Sylvia'a biography of T.H.White which had just come out to wonderful reviews, both here and in the States, where her New Yorker short stories had long made her famous. She had never met White but Michael Howard, in choosing her to write his Life, knew that if he could persuade her to write the biography of this English schoolboy-man and genius that only she would be able to reach him, as it were. And she did. Her only other biography was of a tortoise. White was ever this, someone so massively protected by his shell that it was near impossible to reach him. Rather it was the open nature of his strangeness, its flamboyance even, which could have put a woman off. And Sylvia did indeed, as she confessed, agree somewhat reluctantly to Michael Howard's proposal. She described how she began to arrange Tim White's letters, diaries and papers up the side of her staircase. And then of course, with such a commission, how could she write what she normally wrote, and so wonderfully, fiction? She gave me a copy of T.H. White with its Aegean blue cover and a photo of her subject, in profile and his shirt sleeves, staring forth, the very rich - by now - creator of Camelot.

But my love of Sylvia came from her short stories and one novel in particular, The Corner That Held Them (1948). She had the great fortune to live during one of the greatest short story periods, one filled with the work of Elizabeth Bowen, A.E. Coppard, H.E. Bates, Denton Welch, V.S. Pritchett, Flannery O'Connor, the Deep South storytellers, Calvino ... the names and the lists are endless, as were it seemed would 
be the magazines which demanded them. Sylvia's of course were mostly in The New Yorker. Mine were in The London Magazine, the New Statesmen and in a series edited by my friend James Turner, and on the radio. I had a collection called Immediate Possession published in 1961 and was silenced when Sylvia said that she knew it.

On the day she came to my house French's Folly in Debach, I discovered that she had Suffolk connections going way back. She and Valentine Ackland used to stay in Lavenham during the early Thirties - as did Stephen and Humphrey Spender and their wives - and it was driving from there on 12th January 1931 that they committed themselves to each other. Lavenham then was a small medieval town which as the contemporary guidebooks said had been by-passed by Time. Patched plaster covered most of its beams. Fat cushions of stonecrop grew on its pantiles and pintiles. Gypsies wintered on its common. Fireweed bloomed between its cobbles. The Salvation Army band played to farmworkers in the square on Saturday nights. Harvests were cut at the end of its streets. Its tremendous church attracted bellringers for miles. It was wonderfully quiet - and cheap if you wanted to paint or write.

Sylvia's interest in East Anglia spread to Norfolk during the Thirties when she and Valentine were taken to meet the fisherman-artist John Craske whom Sylvia likened to John Clare and called 'an Intuitive'. She introduced him to Peter Pears and I remember receiving a Craske boat Christmas card from him and Ben, its dark sails lurching over a wild sea. Craske died in 1943 but he remained a vital element to Sylvia and she talked about him as indeed an earlier writer might have talked about Clare. At the moment when she appeared in my ancient room at Debach, with the holly-wood fire crackling away and the November day failing, $\mathrm{I}$ had just read The Corner That Held Them and was quite overwhelmed by its extraordinary 'entry', as it were, into the fourteenth century and, as in her later novel The Flint Anchor (1954) the strange ability which Sylvia possessed to show flesh and blood, fenland and stony coasts, human strivings and hard weather, all coming together in some little relentless place, such as Oby or Loseby. The Corner That Held Them is one of 
the best post-war historical novels. It is also prophetic. Those who are intrigued by the various factors which would eventually bring about the ordination of women to the Anglican priesthood should read it.

Shortly after our meeting, in January 1968, and also just after they had celebrated the 37th anniversary of their devoted friendship, Sylvia learned of Valentine's breast cancer. She died in November 1969 and Sylvia sent me and all their friends Valentine's poem 'Spring, Summer, Autumn, Winter', the last verse of which says,

From the white swan flying invisibly;

Whose wing-beats matched the heart-beats of the night, Fell the light scatter of feathers, transient and bright, Nor spread like a cloak over the naked morning.

Sitting by Valentine's bedside Sylvia had written in her diary, 'This morning the swans flew over'. Later she sent me more of Valentine's poems and we wrote the kind of letters which did not make demands. Clare Harman in her biography and William Maxwell in his editing of the correspondence, have, between them, told the full story more or less. What I hear is the loud, assured old-fashioned voice with its wit and warmth. Michael and Pat Howard, who had so briefly brought us together, left their Suffolk hall for a Welsh castle, and for a great tragedy. Sylvia, and Benjamin Britten and Peter Pears, were guests there at different times. After Michael Howard's death his widow married a Suffolk schoolmaster, Brian Bullen, and they went to live in the Kilvert country near Clyro, where I sometimes stayed with them. Their house was joined to a Welsh chapel and on Sundays we could listen to the singing through the wall. Sylvia would have loved it, we imagined.

Maiden Newton, 12: viii: 1968

Dear Ronald,

I am delighted to hear you are doing Hazlitt. High time; he has been evaded far too long. Dont forget to include Sarah's (Mrs H's) remarkable feats of walking in the Highlands. I computed 
them once, \& found she made as good a pace, or slightly better, as Napoleon's army in the march from Boulogne to Ulm[?]

And I look forward very much to your 'Suffolk Village'.

Thankyou for the cutting of the cottage near Saxmundham. I'm afraid our plan of moving to Suffolk was a flash in the pan. There were so many practical advantages of staying here - trees we have planted and watered grow, tamed tradespeople and the ideal gardener-cum-househelp, that we decided to be pusillanimous and stay.

Ever Sylvia

\section{Copyrighted image removed}

Dust Jacket illustration by Carol Barker, Chatto \& Windus, 1960 